\title{
Comparative Analysis of RNAi Suppression Activity of Proteins from Two Disparate Viruses
}

\author{
Sudhanshu Sekhar Das, Neeti Sanan-Mishra \\ Plant Molecular Biology Group, International Centre for Genetic Engineering and Biotechnology, New Delhi, \\ India \\ Email: ssdas@icgeb.res.in, neeti@icgeb.res.in
}

Received 19 March 2014; revised 17 April 2014; accepted 11 May 2014

Copyright @ 2014 by authors and Scientific Research Publishing Inc.

This work is licensed under the Creative Commons Attribution International License (CC BY). http://creativecommons.org/licenses/by/4.0/

c) (i) Open Access

\section{Abstract}

RNAi is an efficient surveillance machinery that plays a robust defensive role in shielding plant and animal hosts against viral infections. In counter-defense viruses encode suppressor proteins that have the ability to restrict the RNAi machinery to ensure successful systemic invasion. The B2 protein of insect Flock House Virus (FHV-B2) and AC2 protein of Mungbean Yellow Mosaic India Virus (MYMIV-AC2) are two well-characterized suppressors of RNAi, capable of reversing reporter gene silencing. In this study, we compared the strength of the two suppressors by assaying for the degree of RNAi reversion and the duration of sustaining the reversal in planta. The suppression activity was observed by assaying for GFP fluorescence at $3 \mathrm{dpi}, 7 \mathrm{dpi}$ and $14 \mathrm{dpi}$. The phenotypic observations were corroborated with small RNA Northern Blotting and semi-quantitative RT-PCR. The results indicate that suppressor strength of FHVB2 is comparable to MYMIV-AC2, although they are encoded by virus infecting host from two different eukaryotic kingdoms. This study will provide new insights to dissect the conservation in the RNAi pathways during the host-virus interactions.

\section{Keywords}

MYMIV-AC2, FHVB2, Agroinfiltration, RNA Silencing Suppressor (RSS), Reversal of GFP Silencing Assay

\section{Introduction}

RNA silencing is a conserved sequence specific method of gene regulation and one of the potent antiviral de- 
fense mechanisms in a wide variety of organisms [1]-[4]. The hallmark of its antiviral role is the accumulation of virus derived siRNA at high levels during viral infection [5]. Additionally, it was observed that the plant mutants defective in one or several of the RNA silencing pathways were more susceptible to virus infection [6]-[9]. It was then observed that certain pairs of co-infecting viruses caused synergistic viral diseases. This led to the identification of proteins, encoded by many viruses, called the RNA silencing suppressors (RSS) that have the ability to counteract antiviral silencing and play an important role in virulence [10] [11]. Ever since the discovery of first RSS, around 30 plant and animal RSS have been identified [11]-[14]. The RSS mainly inhibit the host defense response by interacting with the key components of host RNA silencing machinery. The lack or inactivation of RSS in viruses leads to the recovery of plants from viral infection [15] [16]. Thus, the RSS, acquired by plant viruses, constitutes a strong weapon in the arm race between plant and invading viruses. However, besides the commonality that they can suppress RNA silencing, the RSS from different viruses differ in evolution, origin, sequence, protein 3D-structure, and in mode of action [17]. As the RSS play an important role in one or many intermediate steps to arrest intracellular and/or intercellular host silencing machinery, they can serve as important tools to dissect the detailed RNA silencing pathways and also to evolve antiviral strategies [18]-[20].

Amongst the plant viruses, Geminiviruses are regarded as one of the most destructive pathogens for vegetable, field and fiber crops that are either economically significant or are staple food [21]. Mungbean Yellow Mosaic India Virus (MYMIV) is a bipartite Begomovirus causing yellow mosaic disease of mungbeans leading to leaf discoloration and yield losses [22]. MYMIV expresses the small protein AC2 (MYMIV-AC2), which is a multitasking pathogenic factor as it trans-activates the late viral genes and develops disease symptom. MYMIV-AC2 has also been well characterized as a RSS. The AC2 protein has a modular structure consisting of N-terminal Nucleus Localization Signal (NLS), a central DNA binding zinc-finger motif and C-terminal acidic activator domain [23]. It is shown that its suppression activity is dependent upon all three functional domains [24].

The best studied amongst the non-plant virus-encoded RSS is the B2 protein encoded by Flock House Virus (FHV-B2) from Nodaviridae family [25]. The FHV-B2 is a small, 106 amino acid containing, protein that is translated from subgenomic RNA3 and accumulates to high levels during infection [25] [26]. Efficient replication of FHV RNAs and formation of progeny virus particles is critically dependent on expression of B2 protein. It also counteracts the silencing of viral gene expression and acts as a broad-spectrum inhibitor of RNAi [25]. Studies on the mode of action revealed that the FHVB2 protein binds with high affinity (Kd-1 nM) to long double-stranded RNA as well as single-stranded RNA via its N-terminal in sequence-independent manner. It also prevents Dicer mediated cleavage and subsequent generation of siRNA [26]-[28]. It has been shown that FHVB2 has the capability of binding tightly to siRNAs thereby preventing incorporation into RISC and thus inhibiting cleavage of target RNAs. Systemic mutagenesis studies on FHVB2 regions demonstrated that the deletion of 17 amino acids from the C-terminus resulted in drastic reduction in RSS activity in comparison to the N-terminal deletions [29]. It has also been shown that FHVB2 protein suppresses RNAi by interacting with PAZ domain of DICER-1/-2 proteins [30]. The initial observation suggesting a role of FHV-B2 as a potent RSS was exhibited in the Agrobacterium co-infiltration assays established in green fluorescent protein (GFP) transgenic plants that could not express the reporter gene [31]. It has been suggested that the FHVB2 gene shares key features, but not sequence similarity, with the plant RSS [11] [32].

The viral encoded RSS are usually thought to act at distinct steps of the silencing machinery, there has been no consensus system recognized so far. The biological application of RSS not only requires identification of suppressors from individual virus groups but a detailed characterization of the suppressor strength and the range of suppressor activity. Identification of the RSS has now become an integral part of virus characterization. In plants a number of assays have been developed, based on the suppression of RNA silencing of a reporter transgene. The transgene may be silenced constitutively [33] or locally by infiltration with an Agrobacterium strain carrying a Ti plasmid harbouring the same gene, referred to as agro-infiltration [34] [35]. The suppression of silencing is assayed by introducing, the candidate protein into the silenced plants by a replicating virus vector, genetic crosses or agro-infiltration and observing the reversal of silencing. The ubiquity of silencing suppression and the plethora of functional assays currently available for their discovery have made identification of new silencing suppressors an almost trivial task. However, there is a lacuna in defining the parameters for assaying the strength of suppressors using the available in-planta assay system. Since most of the earlier work on the RSS involved model systems that differ in terms of host, transgene used or the method of delivery, it was difficult to correlate the degree of silencing ability and viral pathogenicity [36]. To address this issue we have tried to define parame- 
ters for comparing the suppressor strength of two well-known RSS, viz FHVB2 and MYMIV-AC2 protein by utilizing an in-planta reversal of GFP silencing assay.

\section{Methods}

\subsection{Plasmid Construct}

The AC2 protein of Mungbean Yellow Mosaic India Virus (MYMIV-AC2) and B2 protein of Flock House Virus (FHV-B2) were cloned into binary vector pBI121 under the CaMV 35S promoter and NOS terminator. The transformants were analyzed by restriction analysis, PCR and plasmid DNA sequencing. The R53Q mutant of FHVB2, a point mutation which abolishes the suppression activity of FHVB2 was also used in the study [37]. To generate a RSS defective protein, R53Q point mutation was introduced into the FHVB2 coding region by PCRmediated mutagenesis with forward primer 5'-ACGGTAAGTCAAATGGTAACATCAC-3' and reverse primer 5'-GTGATGTTACCATTTGACTTACCGT-3' (the mutant positions are underlined). The B2(R53Q) mutant was cloned into a pGEMTeasy vector (Promega) which was subsequently confirmed via nucleotide sequencing. The B2(R53Q) ORF was then moved to pBI121 binary vector under CaMV 35S promoter and NOS terminator. The recombinant plasmids (pBI121-B2, pBI121-MYMIV-AC2 and pBI121-B2(R53Q)) were mobilized into Agrobacterium tumefaciens strains LBA4404 cells, followed by infiltration of the leaves of GFP silenced Nicotiana tabacum plants.

\subsection{Agroinfiltration}

Agrobacterium-mediated reversal of GFP expression in GFP silenced Nicotiana tabacum L. cv. Xanthi leaves was achieved through pressure infiltration, as described previously [38]. Briefly, Agrobacterium culture was grown until reaching an optical density of 1.0 at $600 \mathrm{~nm}$ (OD600). The culture was treated with $200 \mu \mathrm{M}$ acetosyringone (AS) for $1 \mathrm{hr}$ prior to infiltration. The homogenous culture mixture was infiltrated in the young leaves with the help of needleless syringe by generating a vacuum with the help of finger on the dorsal side of the leaf and mouth of the syringe on the ventral side. After 3, 7 or 14 days after inoculation (dpi) the leaf was visualized under UV for fluorescence.

\subsection{Reverse Transcriptase Polymerase Chain Reaction (RT-PCR)}

For semi-quantitative RT-PCR, cDNA were prepared in $20 \mu \mathrm{l}$ reactions from total RNA isolated from the infiltrated leaf tissues, using $50 \mathrm{U}$ of Super Script TM II reverse transcriptase (Invitrogen) and random hexamers. The first strand cDNA of total RNA were subjected to DNaseI treatment for $30 \mathrm{~min}$. The PCR program for the amplification of GFP and suppressor genes (MYMIV-AC2, FHVB2, FHVB2(R53Q)) were carried out using gene specific primers (Suppl File 1) at initial sample denaturation at $95^{\circ} \mathrm{C}$ for 5 min followed by 25 cycles of strand separation at $94^{\circ} \mathrm{C}$ for $1 \mathrm{~min}$, annealing at $56^{\circ} \mathrm{C}$ for $30 \mathrm{~s}$ and extension at $72^{\circ} \mathrm{C}$ for $30 \mathrm{~s}$. The program was extended for $7 \mathrm{~min}$ at $72^{\circ} \mathrm{C}$. The tobacco $18 \mathrm{~S}$ gene was used as a constitutive internal standard to evaluate cDNA content. The amplification products were analyzed on $0.8 \%$ agarose gel. The band intensities were quantified using Alpha Imager Imaging System.

\subsection{Small RNA Northern Blot Analysis}

Total RNA was extracted from infiltrated leaves using the guanidium thiocynate extraction method [39]. $30 \mu \mathrm{g}$ of total RNA from each plant sample was resolved on a $15 \%$ polyacrylamide gel and transferred on Hybond $\mathrm{N}+$ membranes (Amersham Pharmacia). Prehybridization was performed in 30\% formaldehyde hybridization buffer for 2 hrs with mild agitation at $42^{\circ} \mathrm{C}$ followed by hybridization with GFP probe for 14-16 hrs. The probe was prepared using $\alpha\left[{ }^{32} \mathrm{P}\right] \mathrm{dCTP}$ labelled cDNA of FHVB2 that spanned the entire coding sequence [39]. Following the hybridization, the blot was washed with $0.5 \mathrm{X}$ SSC, $0.1 \%$ SDS for 30 min and analyzed in phosphoimager.

\subsection{Multiple Sequence Alignment}

Nucleotide sequence of MYMIV-AC2 (JX110618.1) and FHVB2 (NC_004146.1) as well as protein sequence of MYMIV-AC2 (AFP58801.1) and FHVB2 (NP_689446.1) were aligned using Clustal Omega (http://www.ebi.ac.uk/Tools/msa/clustalo/) with default parameter. 


\section{Results and Discussion}

\subsection{In Planta Comparison of RSS Activity}

The virus encoded RSS represents an excellent example of the continuing evolutionary arms race between host and virus. The RSS from individual virus groups or even within the groups behave differently and suppress the RNA silencing pathway by a different mechanism. In this study we compared the suppressor strength of two well-characterized RSS viz. AC2 of MYMIV (a virus infecting plants mainly legume crops) [24] and B2 of FHV (virus infecting animals mainly insects) [25]. These two proteins differ in their origin and mode of action, yet they are capable of reversing the silencing of green fluorescent protein (GFP) in Agrobacterium co-infiltration assays [40]. Both MYMIV-AC2 and FHVB2 showed no significant sequence similarity $(e<10)$ at the nucleotide level (Figure 1(a)). Their protein sequences showed only 20.22\% similarity with no common domain between the two (Figure 1(b)). This clearly suggests that the RSS activity is not sequence-dependent. Although many examples of RSS identification using in planta assays are available [41]-[43], but till date there is no report on the comparison of their suppressor strengths. Moreover, the use of different model system used for RSS studies, makes it more difficult to compare the outcome [36].

\begin{tabular}{|c|c|}
\hline $\begin{array}{l}\text { FHVB2 } \\
\text { MYMIV-AC2 }\end{array}$ & $\begin{array}{l}\text { ATGCCAAGCAAACTCGCGCTAATCCAGGAA } \\
\text { CTACGGAAGATCGATAAGATCATCCCAGAAGTCGCCGTCAAATAGTGGAAGAGCTTCAAT } \\
\star \star \star \star \star * \star \star \star \star * \star *\end{array}$ \\
\hline $\begin{array}{l}\text { FHVB2 } \\
\text { MYMIV-AC2 }\end{array}$ & 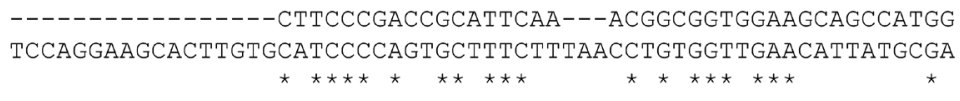 \\
\hline $\begin{array}{l}\text { FHVB2 } \\
\text { MYMIV-AC2 }\end{array}$ & 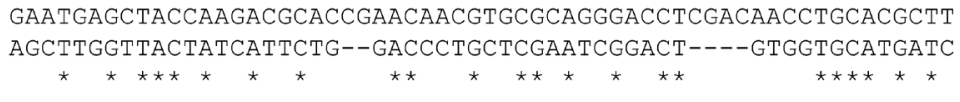 \\
\hline $\begin{array}{l}\text { FHVB2 } \\
\text { MYMIV-AC2 }\end{array}$ & 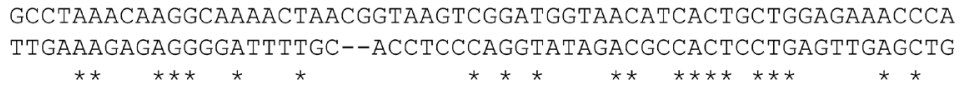 \\
\hline $\begin{array}{l}\text { FHVB2 } \\
\text { MYMIV-AC2 }\end{array}$ & 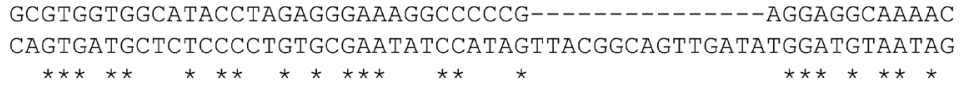 \\
\hline $\begin{array}{l}\text { FHVB2 } \\
\text { MYMIV-AC2 }\end{array}$ & $\begin{array}{l}\text { CAACACTCGAAGAACGCCTCCGAAAGCTGGAGCTCAGCCACAG------------ } \\
\text { CTACACCCACACTTCAGGTC---AATTCGAGATCGTCGAATTGCTCTCTTCTTGGCGAC } \\
* * * * * * * * * * * * * * * *\end{array}$ \\
\hline $\begin{array}{l}\text { FHVB2 } \\
\text { MYMIV-AC2 }\end{array}$ & 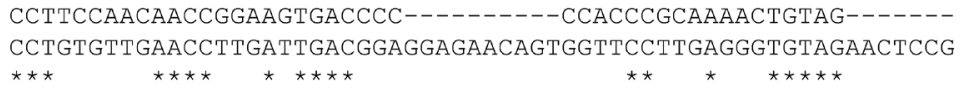 \\
\hline $\begin{array}{l}\text { FHVB2 } \\
\text { MYMIV-AC2 }\end{array}$ & $\begin{array}{l}--- \\
\mathrm{CAT}\end{array}$ \\
\hline
\end{tabular}

(a)

\begin{tabular}{|c|c|}
\hline FHVB2 & --------- MPSKLALIQELPDR---IQTAVEAAMGMSYQDAPNN--VRRDLDNLHAC \\
\hline \multirow[t]{2}{*}{ MYMIV-AC2 } & MRSSTPSRNHCSPPS IKVQHRVAKKRAIRRSRIDLKCGCSYYIHINCRNYGYSHRGEHHC \\
\hline & * $.: \quad: \quad:: \quad .:$ \\
\hline FHVB2 & LNKAKLTVSRMVTSLLEKPSVVAYLEGK--------APEEAKPTLEERLRKLELSHSL-P \\
\hline \multirow[t]{2}{*}{ MYMIV-AC2 } & SSTQE---------------WRLYLGGAKSPLFQDHAPQSDSSRVQNDSN--QASHNVQP \\
\hline & ${ }^{\star}: \cdot \cdot \quad::: \quad \cdot \quad: \quad * \star .: *$ \\
\hline FHVB2 & ----TTGSDP---PPAKL--------------- \\
\hline \multirow[t]{2}{*}{ MYMIV-AC2 } & QVKESTGDAQVLPGIEALPLFDGDFWDDLIDLP \\
\hline & $: * \star$ \\
\hline
\end{tabular}

(b)

Figure 1. Sequence Alignment of MYMIV-AC2 and FHV-B2. (a) Nucleotide and (b) Amino Acid sequence alignments were performed using the Clustal-Omega program. 
To analyze the RSS activity of MYMIV-AC2 and FHVB2 transient reversal of silencing assays were performed using in-house developed naturally silenced GFP lines [44] [45]. The construct of FHVB2 (R53Q) mutant was used as control. The leaves of the GFP silenced lines were agro-infiltrated and analyzed for GFP expression after 3, 7 and 14 days post infiltration (dpi) (Figure A1). The infiltrated zones on the leaves exhibited positive reversal of silencing in the MYMIV-AC2 and FHV-B2 infiltrated zones, appearing as fluorescent green of GFP ( $\sim 510 \mathrm{~nm}$ ) upon UV illumination at 365nm, while the FHVB2(R53Q) mutant failed to revert the silencing (Figure 2). The GFP fluorescence started appearing at 3 dpi and increased by 7 dpi. At 14 dpi a drop in the fluorescence signal was observed. This indicated that the Agrobacterium mediated transient expression of the RSS could sustain the reversal of GFP silencing for a period of about 14 days. The FHVB2 (R53Q) mutant, which lacks the suppression activity [30], was not able to sustain the GFP expression.

\subsection{Parameters for Comparison of RSS Activity}

To define the strength of RSS activity two parameters were used that were based on the degree of GFP reversal and the sustenance of GFP expression. Molecular approaches were employed to quantitate the degree of GFP reversal due to the RSS activity by comparing the GFP reporter transcript (Figure 3(a)) with respect to the amount of RSS transcript present (Figure 3(b)). It was observed that in presence of MYMIV-AC2 the GFP bands appeared at 3 dpi and showed an increase till 14 dpi (Figure 3(a)). In presence of FHVB2 the GFP transcripts appeared at $7 \mathrm{dpi}$ and increased till $14 \mathrm{dpi}$, whereas GFP accumulation was not observed in presence of FHVB2 (R53Q) mutant (Figure 3(a)). The GFP band intensities appeared higher in FHV-B2 infiltrated zones than in MYMIV-AC2 infiltrated zones.

The suppressor strength was calculated in terms of "S" value, by normalizing the accumulated GFP transcripts with respect to the RSS transcript. The values obtained were plotted and compared (Figure 3(c)). This revealed that the suppression activity of FHVB2 started early and was sustained till 14 dpi. In case of MYMIV-AC2 the initiation of suppression activity increased rapidly with time and peaked at $7 \mathrm{dpi}$. This level was maintained till 14 dpi. Thus MYMIV-AC2 appeared to be stronger suppressor. Amongst the plant viruses, a huge variability has been observed amongst the AC2 proteins encoded by different species of the genus Begomovirus. It has been reported that East African Cassava Mosaic Cameroon Virus (EACMCV)-AC2 and the Indian Cassava Mosaic Virus (ICMV)-AC2 act as strong suppressor of RNA silencing, while the African cassava mosaic virus (ACMV[CM])-AC2 and Sri Lankan Cassava Mosaic Virus (SICMV)-AC2 as weak suppressors [46]. Moreover, different viral strains show different degree of pathogenicity ranging from mild to severe, so probably AC2, which is a pathogenicity determinant also show corresponding variations in its activity.

The levels of the GFP-siRNA were also quantitated (Figure 4(a)) and correlated to the sustenance of reversal of GFP silencing over the defined time period. A direct correlation between the GFP expression and suppressor

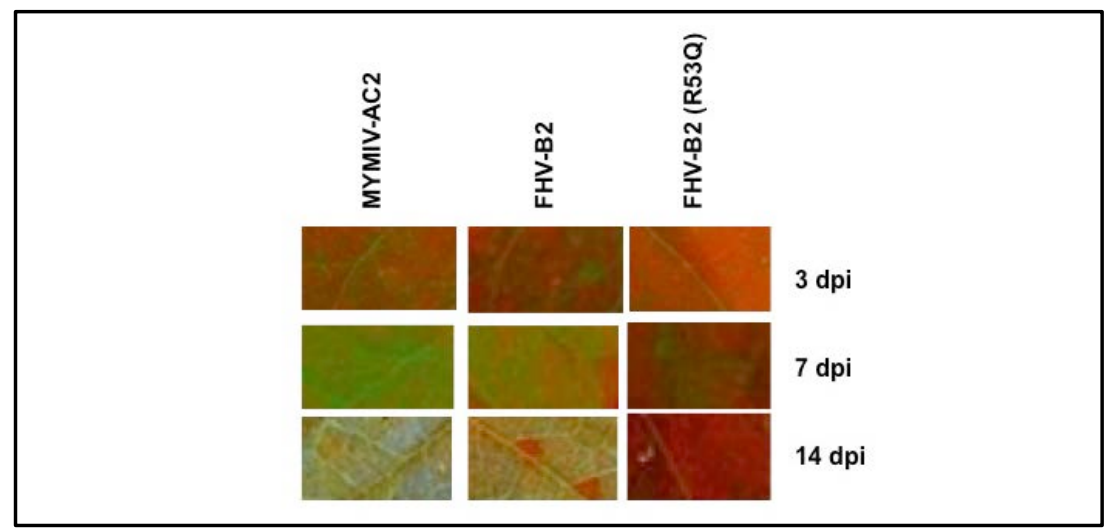

Figure 2. The reversion of GFP expression in GFP-silenced tobacco leaves. GFP-silenced tobacco leaves were agroinfiltrated with MYMIV-AC2, FHV-B2 and FHV-B2 (R53Q) as a negative control. The infiltrated zones of MYMIV-AC2, FHV-B2 and FHV-B2 (R53Q) were analysed for GFP fluorescence under UV lamp where they exhibited a reversal of GFP at 3 dpi, 7 dpi and 14 dpi of agroinfiltrated leaves. Each of the leaves was labeled at the top for the construct with which it was infiltrated. 


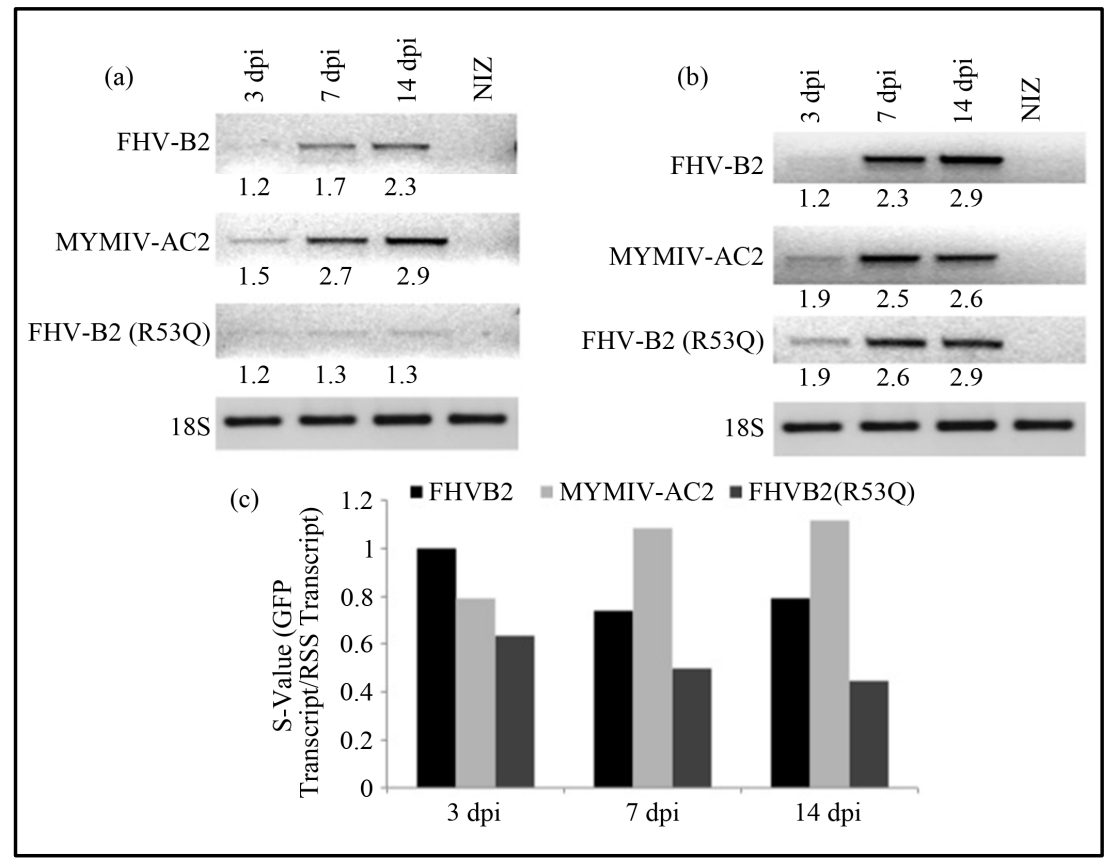

Figure 3. Analyzing the transcript levels of GFP and RSS. Reverse transcriptase polymerase chain reaction (RT-PCR) analysis of (a) GFP transcripts and (b) suppressor transcripts in total RNA obtained from GFP-silenced Nicotiana tabaccum cv. Xanthi leaves infiltrated with MYMIV-AC2, FHV-B2 and FHV-B2 (R53Q) and analyzed at 3 dpi, 7 dpi and 14 dpi, using GFP specific primers. The non-infiltrated zone (NIZ) RNA served as negative control. cDNA was prepared using $50 \mathrm{U}$ of Super ScriptTM II reverse transcriptase (Invitrogen). Lane 1: 3 dpi, Lane 2: 7 dpi, Lane 3: 14dpi and Lane 4: non-infiltrated zone (NIZ). The figures below each band represent the intensities of the GFP band on the blot normalized with respect to 18S rRNA. The band intensities were measured by Alpha Imager Imaging System. (c) The graph represents the suppressor strength calculated in terms of "S" value, by normalizing the accumulated GFP transcripts with respect to the RSS transcript.

expression was observed. At 3 dpi MYMIV-AC2 was able to considerably reduce the amount of GFP siRNA. In case of FHV-B2 this reduction was achieved at $7 \mathrm{dpi}$. In both cases this response was sustained up to $14 \mathrm{dpi}$. The ectopic expression of MYMIV-AC2 and FHV-B2 led to reduction of biogenesis of small interfering RNA (siRNA). In contrast the negative control FHV-B2 (R53Q) (Figure 4(a)) infiltration did not change the siRNA level for the entire period. These results suggest that the FHV-B2 is a stronger quencher of the siRNAs.

To compare the sustenance of siRNA down regulation, the siRNA intensities were normalized with respect to the RSS transcript. The values obtained were plotted and compared (Figure 4(b)). This revealed that the RSS activity of MYMIV-AC2 started to down regulate the GFP siRNA at 3 dpi and the response was sustained till 14 dpi. In case of FHVB2 the initiation of suppression activity was delayed. It appeared at 7 dpi but it increased rapidly and at 14 dpi FHV-B2 mediated siRNA down regulation was more than that of MYMIV-AC2.

For both the suppressors the "S" value was determined and it was observed that their RSS activity could be sustained to 14 dpi. Thus it emerged that though MYMIV-AC2 has a higher "S" value and could reverse the GFP expression to a greater level, the FHV-B2 is a stronger quencher of the siRNAs. This also reflects the mechanism of suppressor action, as the RSS encoded by different plant viruses appear to suppress this virus defense pathway at different points (Figure 5). It needs to be tested whether the high "S" value corresponds to high pathogenicity.

\section{Conclusion}

This study will be useful in developing a cataloguing system for RNAi suppressors for use as probes for understanding the mechanism of host-virus interactions. The different RNAi suppressors can be manipulated as tools 


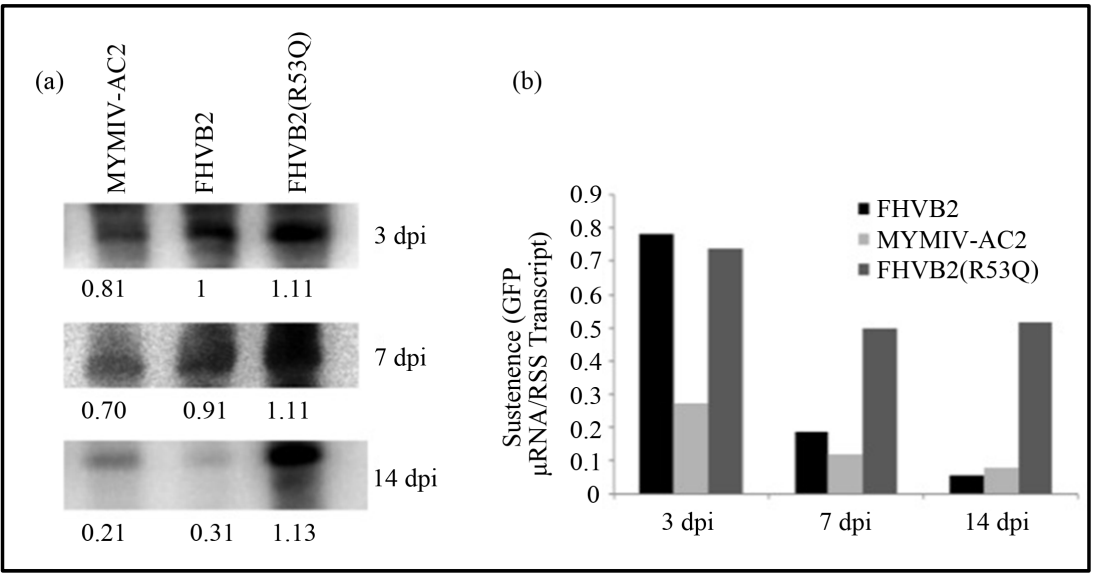

Figure 4. Small RNA analysis. (a) Northern blot RNA preparations from leaves GFPsilenced Nicotiana tabaccum cv. Xanthi infiltrated with MYMIV-AC2, FHV-B2 and FHV-B2 (R53Q) were analyzed at $3 \mathrm{dpi,} 7 \mathrm{dpi}$ and 14 dpi by Northern blot. $30 \mu \mathrm{g}$ of total RNA prepared from the leaf tissue was used for hybridizations with ${ }^{32} \mathrm{P}$ labelled full length GFP probe. Lane 1: MYMIV-AC2; Lane 2: FHV-B2; Lane 3: FHVB2 (R53Q). The figure above shows the intensities of the GFP siRNA band on the blot normalised against 28S rRNA. The band intensities were quantified using Alpha Imager Imaging System. (b) The graphical representation of the siRNA intensities normalized with respect to the RSS transcript.

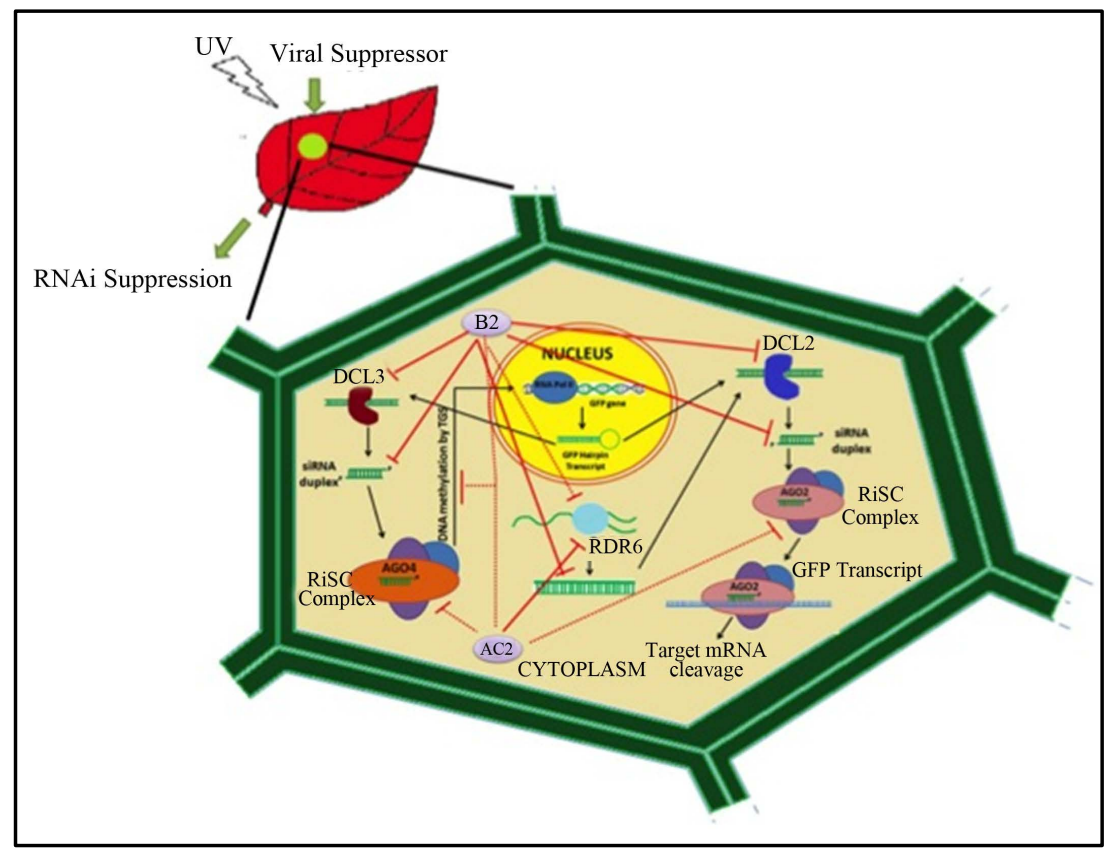

Figure 5. Diagrammatic representation of B2 and AC2 RNAi suppressor and their interference site on RNAi pathway.

for enhancing plant viral resistance as well as the expression of genes related to molecular farming in transgenic plants.

\section{Acknowledgements}

The authors would like to thank Dr. Sunil K. Mukherjee and Dr. Raj K. Bhatnagar for providing the MYMIVAC2 and FHV-B2 gene constructs. The authors would like to thank Prof. Sudhir K. Sopory for critically reading 
the manuscript. SSD acknowledges the fellowship received from CSIR, India. The research was supported by financial grants received from the Department of Biotechnology, Government of India.

\section{References}

[1] Hamilton, A., Voinnet, O., Chappell, L. and Baulcombe, D. (2002) Two Classes of Short Interfering RNA in RNA Silencing. The EMBO Journal, 21, 4671-4679. http://dx.doi.org/10.1093/emboj/cdf464

[2] Aravin, A.A., Naumova, N.M., Tulin, A.V., Vagin, V.V., Rozovsky, Y.M. and Gvozdev, V.A. (2001) Double-Stranded RNA-Mediated Silencing of Genomic Tandem Repeats and Transposable Elements in the D. melanogaster Germline. Current Biology, 11, 1017-1027. http://dx.doi.org/10.1016/S0960-9822(01)00299-8

[3] Baulcombe, D. (2004) RNA Silencing in Plants. Nature, 431, 356-363. http://dx.doi.org/10.1038/nature02874

[4] Matzke, M.A. and Birchler, J.A. (2005) RNAi-Mediated Pathways in the Nucleus. Nature Reviews Genetics, 6, 24-35. http://dx.doi.org/10.1038/nrg1500

[5] Voinnet, O. (2001) RNA Silencing as a Plant Immune System against Viruses. Trends in Genetics, 17, 449-459. http://dx.doi.org/10.1016/S0168-9525(01)02367-8

[6] Boutet, S., Vazquez, F., Liu, J., Beclin, C., Fagard, M., Gratias, A., Morel, J.B., Crete, P., Chen, X. and Vaucheret, H. (2003) Arabidopsis HEN1: A Genetic Link between Endogenous miRNA Controlling Development and siRNA Controlling Transgene Silencing and Virus Resistance. Current Biology, 13, 843-848. http://dx.doi.org/10.1016/S0960-9822(03)00293-8

[7] Dalmay, T., Hamilton, A., Rudd, S., Angell, S. and Baulcombe, D.C. (2000) An RNA-Dependent RNA Polymerase Gene in Arabidopsis Is Required for Posttranscriptional Gene Silencing Mediated by a Transgene but Not by a Virus. Cell, 101, 543-553. http://dx.doi.org/10.1016/S0092-8674(00)80864-8

[8] Mourrain, P., Beclin, C., Elmayan, T., Feuerbach, F., Godon, C., Morel, J.B., Jouette, D., Lacombe, A.M., Nikic, S., Picault, N., Remoue, K., Sanial, M., Vo, T.A. and Vaucheret, H. (2000) Arabidopsis SGS2 and SGS3 Genes Are Required for Posttranscriptional Gene Silencing and Natural Virus Resistance. Cell, 101, 533-542. http://dx.doi.org/10.1016/S0092-8674(00)80863-6

[9] Wilkins, C., Dishongh, R., Moore, S.C., Whitt, M.A., Chow, M. and Machaca, K. (2005) RNA Interference Is an Antiviral Defence Mechanism in Caenorhabditis elegans. Nature, 436, 1044-1047. http://dx.doi.org/10.1038/nature03957

[10] Baulcombe, D. (2002) Viral Suppression of Systemic Silencing. Trends in Microbiology, 10, 306-308. http://dx.doi.org/10.1016/S0966-842X(02)02387-9

[11] Brigneti, G., Voinnet, O., Li, W.X., Ji, L.H., Ding, S.W. and Baulcombe, D.C. (1998) Viral Pathogenicity Determinants Are Suppressors of Transgene Silencing in Nicotiana benthamiana. The EMBO Journal, 17, 6739-6746. http://dx.doi.org/10.1093/emboj/17.22.6739

[12] Anandalakshmi, R., Pruss, G.J., Ge, X., Marathe, R., Mallory, A.C., Smith, T.H. and Vance, V.B. (1998) A Viral Suppressor of Gene Silencing in Plants. Proceedings of the National Academy of Sciences of the USA, 95, 13079-13084. http://dx.doi.org/10.1073/pnas.95.22.13079

[13] Kasschau, K.D. and Carrington, J.C. (1998) A Counter Defensive Strategy of Plant Viruses: Suppression of Posttranscriptional Gene Silencing. Cell, 95, 461-470. http://dx.doi.org/10.1016/S0092-8674(00)81614-1

[14] Artimo, P., Jonnalagedda, M., Arnold, K., Baratin, D., Csardi, G., de Castro, E., Duvaud, S., Flegel, V., Fortier, A., Gasteiger, E., Grosdidier, A., Hernandez, C., Ioannidis, V., Kuznetsov, D., Liechti, R., Moretti, S., Mostaguir, K., Redaschi, N., Rossier, G., Xenarios, I. and Stockinger, H. (2012) ExPASy: SIB Bioinformatics Resource Portal. Nucleic Acids Research, 40, W597-W603. http://dx.doi.org/10.1093/nar/gks400

[15] Ziebell, H., Payne, T., Berry, J.O., Walsh, J.A. and Carr, J.P. (2007) A Cucumber Mosaic Virus Mutant Lacking the 2b Counter-Defence Protein Gene Provides Protection against Wild-Type Strains. Journal of General Virology, 88, 28622871. http://dx.doi.org/10.1099/vir.0.83138-0

[16] Silhavy, D., Molnar, A., Lucioli, A., Szittya, G., Hornyik, C., Tavazza, M. and Burgyan, J. (2002) A Viral Protein Suppresses RNA Silencing and Binds Silencing-Generated, 21- to 25-Nucleotide Double-Stranded RNAs. EMBO Journal, 21, 3070-3080. http://dx.doi.org/10.1093/emboj/cdf312

[17] Anand, A., Mukherjee, S.K. and Sanan-Mishra, N. (2013) Tools for Pathogenicity: Virus Encoded RNA Silencing Suppressors. In: Mendez-Vilas, A., Ed., Recent Microbial Pathogens and Strategies for Combating Them: Science, Technology and Education, Microbiology Book Series, Vol. 1, Formatex Research Center, Spain, 751-763.

[18] Qu, J., Ye, J. and Fang, R.X. (2007) Artificial microRNA-Mediated Virus Resistance in Plants. Journal of Virology, 81, 6690-6699. http://dx.doi.org/10.1128/JVI.02457-06

[19] Niu, Q.W., Lin, S.S., Reyes, J.L., Chen, K.C., Wu, H.W., Yeh, S.D. and Chua, N.H. (2006) Expression of Artificial microRNAs in Transgenic Arabidopsis thaliana Confers Virus Resistance. Nature Biotechnology, 24, 1420-1428. 
http://dx.doi.org/10.1038/nbt1255

[20] Shimura, K., Kodama, E., Sakagami, Y., Matsuzaki, Y., Watanabe, W., Yamataka, K., Watanabe, Y., Ohata, Y., Doi, S., Sato, M., Kano, M., Ikeda, S. and Matsuoka, M. (2008) Broad Antiretroviral Activity and Resistance Profile of the Novel Human Immunodeficiency Virus Integrase Inhibitor Elvitegravir (JTK-303/GS-9137). Journal of Virology, 82, 764-774. http://dx.doi.org/10.1128/JVI.01534-07

[21] Mansoor, S., Briddon, R.W., Zafar, Y. and Stanley, J. (2003) Geminivirus Disease Complexes: An Emerging Threat. Trends in Plant Science, 8, 128-134. http://dx.doi.org/10.1016/S1360-1385(03)00007-4

[22] Usharani, K., Surendranath, B., Haq, Q. and Malathi, V. (2004) Yellow Mosaic Virus Infecting Soybean in Northern India Is Distinct from the Species Infecting Soybean in Southern and Western India. Current Science, 86, 845-850.

[23] Hartitz, M.D., Sunter, G. and Bisaro, D.M. (1999) The Tomato Golden Mosaic Virus Transactivator (TrAP) Is a SingleStranded DNA and Zinc-Binding Phosphoprotein with an Acidic Activation Domain. Virology, 263, 1-14. http://dx.doi.org/10.1006/viro.1999.9925

[24] Trinks, D., Rajeswaran, R., Shivaprasad, P.V., Akbergenov, R., Oakeley, E.J., Veluthambi, K., Hohn, T. and Pooggin, M.M. (2005) Suppression of RNA Silencing by a Geminivirus Nuclear Protein, AC2, Correlates with Transactivation of Host Genes. Journal of Virology, 79, 2517-2527. http://dx.doi.org/10.1128/JVI.79.4.2517-2527.2005

[25] Li, H., Li, W.X. and Ding, S.W. (2002) Induction and Suppression of RNA Silencing by an Animal Virus. Science, 296, 1319-1321. http://dx.doi.org/10.1126/science.1070948

[26] Lu, R., Maduro, M., Li, F., Li, H.W., Broitman-Maduro, G., Li, W.X. and Ding, S.W. (2005) Animal Virus Replication and RNAi-Mediated Antiviral Silencing in Caenorhabditis elegans. Nature, 436, 1040-1043. http://dx.doi.org/10.1038/nature03870

[27] Chao, J.A., Lee, J.H., Chapados, B.R., Debler, E.W., Schneemann, A. and Williamson, J.R. (2005) Dual Modes of RNA-Silencing Suppression by Flock House Virus Protein B2. Nature Structural \& Molecular Biology, 12, 952-957. http://dx.doi.org/10.1038/nsmb1005

[28] Lingel, A., Simon, B., Izaurralde, E. and Sattler, M. (2005) The Structure of the Flock House Virus B2 Protein, a Viral Suppressor of RNA Interference, Shows a Novel Mode of Double-Stranded RNA Recognition. EMBO Reports, 6, 1149-1155. http://dx.doi.org/10.1038/sj.embor.7400583

[29] Singh, G., Korde, R., Malhotra, P., Mukherjee, S. and Bhatnagar, R.K. (2010) Systematic Deletion and Site-Directed Mutagenesis of FHVB2 Establish the Role of C-Terminal Amino Acid Residues in RNAi Suppression. Biochemical and Biophysical Research Communications, 398, 290-295. http://dx.doi.org/10.1016/j.bbrc.2010.06.083

[30] Singh, G., Popli, S., Hari, Y., Malhotra, P., Mukherjee, S. and Bhatnagar, R.K. (2009) Suppression of RNA Silencing by Flock House Virus B2 Protein Is Mediated through Its Interaction with the PAZ Domain of Dicer. FASEB Journal, 23, 1845-1857. http://dx.doi.org/10.1096/fj.08-125120

[31] Li, H.W., Li, W.X. and Ding, S.W. (2002) Induction and Suppression of RNA Silencing by an Animal Virus. Science, 296, 1319-1321. http://dx.doi.org/10.1126/science.1070948

[32] Li, H.W., Lucy, A.P., Guo, H.S., Li, W.X., Ji, L.H., Wong, S.M. and Ding, S.W. (1999) Strong Host Resistance Targeted against a Viral Suppressor of the Plant Gene Silencing Defence Mechanism. EMBO Journal, 18, 2683-2691. http://dx.doi.org/10.1093/emboj/18.10.2683

[33] Palauqui, J.C., Elmayan, T., Pollien, J.M. and Vaucheret, H. (1997) Systemic Acquired Silencing: Transgene-Specific Post-Transcriptional Silencing Is Transmitted by Grafting from Silenced Stocks to Non-Silenced Scions. EMBO Journal, 16, 4738-4745. http://dx.doi.org/10.1093/emboj/16.15.4738

[34] Voinnet, O. and Baulcombe, D.C. (1997) Systemic Signalling in Gene Silencing. Nature, 389, 553-553. http://dx.doi.org/10.1038/39215

[35] Voinnet, O., Vain, P., Angell, S. and Baulcombe, D.C. (1998) Systemic Spread of Sequence-Specific Transgene RNA Degradation in Plants Is Initiated by Localized Introduction of Ectopic Promoterless DNA. Cell, 95, 177-187. http://dx.doi.org/10.1016/S0092-8674(00)81749-3

[36] Voinnet, O. (2005) Induction and Suppression of RNA Silencing: Insights from Viral Infections. Nature Reviews Genetics, 6, 206-220. http://dx.doi.org/10.1038/nrg1555

[37] Ou, M.C., Chen, Y.M., Jeng, M.F., Chu, C.J., Yang, H.L. and Chen, T.Y. (2007) Identification of Critical Residues in Nervous Necrosis Virus B2 for dsRNA-Binding and RNAi-Inhibiting Activity through by Bioinformatic Analysis and Mutagenesis. Biochemical and Biophysical Research Communications, 361, 634-640. http://dx.doi.org/10.1016/j.bbrc.2007.07.075

[38] Karjee, S., Islam, M.N. and Mukherjee, S.K. (2008) Screening and Identification of Virus-Encoded RNA Silencing Suppressors. Methods in Molecular Biology, 442, 187-203. http://dx.doi.org/10.1007/978-1-59745-191-8 14

[39] (1989) In: Sambrook, J., Fritsch, E.F. and Maniatis, T., Eds., Molecular Cloning: A Laboratory Manual, Vol. 1, Cold 
Spring Harbor Laboratory Press, New York.

[40] Voinnet, O., Pinto, Y.M. and Baulcombe, D.C. (1999) Suppression of Gene Silencing: A General Strategy Used by Diverse DNA and RNA Viruses of Plants. Proceedings of the National Academy of Sciences of the United States of America, 96, 14147-14152. http://dx.doi.org/10.1073/pnas.96.24.14147

[41] Lakatos, L., Csorba, T., Pantaleo, V., Chapman, E.J., Carrington, J.C., Liu, Y.P., Dolja, V.V., Calvino, L.F., LópezMoya, J.J. and Burgyán, J. (2006) Small RNA Binding Is a Common Strategy to Suppress RNA Silencing by Several Viral Suppressors. The EMBO Journal, 25, 2768-2780. http://dx.doi.org/10.1038/sj.emboj.7601164

[42] Gouveia, P. and Nolasco, G. (2012) The p19.7 RNA Silencing Suppressor from Grapevine Leafroll-Associated Virus 3 Shows Different Levels of Activity across Phylogenetic Groups. Virus Genes, 45, 333-339. http://dx.doi.org/10.1007/s11262-012-0772-3

[43] Lu, R., Folimonov, A., Shintaku, M., Li, W.X., Falk, B.W., Dawson, W.O. and Ding, S.W. (2004) Three Distinct Suppressors of RNA Silencing Encoded by a 20-kb Viral RNA Genome. Proceedings of the National Academy of Sciences of the United States of America, 101, 15742-15747. http://dx.doi.org/10.1073/pnas.0404940101

[44] Voinnet, O., Lederer, C. and Baulcombe, D.C. (2000) A Viral Movement Protein Prevents Spread of the Gene Silencing Signal in Nicotiana benthamiana. Cell, 103, 157-167. http://dx.doi.org/10.1016/S0092-8674(00)00095-7

[45] Johansen, L.K. and Carrington, J.C. (2001) Silencing on the Spot. Induction and Suppression of RNA Silencing in the Agrobacterium-Mediated Transient Expression System. Plant Physiology, 126, 930-938. http://dx.doi.org/10.1104/pp.126.3.930

[46] Vanitharani, R., Chellappan, P., Pita, J.S. and Fauquet, C.M. (2004) Differential Roles of AC2 and AC4 of Cassava Geminiviruses in Mediating Synergism and Suppression of Posttranscriptional Gene Silencing. Journal of Virology, 78, 9487-9498. http://dx.doi.org/10.1128/JVI.78.17.9487-9498.2004

\section{Appendix}

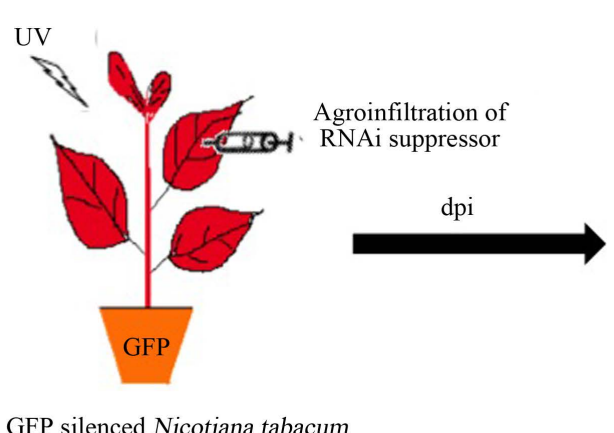

GFP silenced Nicotiana tabacum

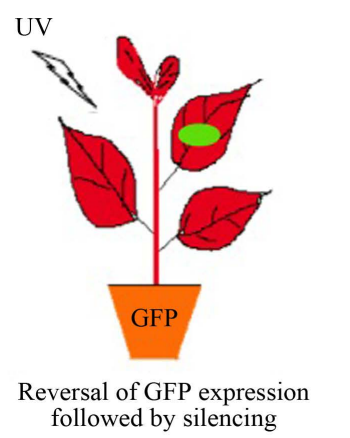

followed by silencing

Figure A1. Schematic representation of in planta assay. 